\title{
The Role of Place Identity, Local Genius, Orange Economy and Cultural Policies for Sustainability of Intangible Cultural Heritage in Bali
}

\author{
Agung Parameswara ${ }^{1,2 *}$, Ida Ayu Nyoman Saskara ${ }^{1}$, Made Suyana Utama ${ }^{1}$, Ni Putu Wiwin Setyari ${ }^{1}$ \\ ${ }^{1}$ Faculty Economic and Business, Udayana University, Bali 80235, Indonesia \\ ${ }^{2}$ Warmadewa Research Centre, Warmadewa University, Bali 80235, Indonesia
}

Corresponding Author Email: agungparameswara@warmadewa.ac.id

https://doi.org/10.18280/ijsdp.160816

Received: 5 November 2021

Accepted: 17 December 2021

\section{Keywords:}

traditional textiles, Bali, sustainable development, orange economy, local genius, place identity, policies

\begin{abstract}
This paper examines the relationship between orange economy activity which is an activity that allow for ideas to be transformed into cultural goods, local genius, place identity, cultural policies, and sustainability intangible cultural heritage (ICH) of Balinese handwoven textiles. A questionnaire survey was administered to 145 respondents. Partial Least Squares-Structural Equation Modelling (PLS-SEM) was applied to the resultant data using SmartPLS 3.0 software. The result revealed local genius, orange economy activity, and place identity have positive and significant influence on sustainability ICH of Balinese handwoven textiles. A positive and significant direct effect between local genius and place identity to the orange economy activity was also found. The result also proved that the orange economy mediates the relationship between local genius and place identity on sustainability. Moreover, cultural policies moderates the relationship between orange economy and sustainability. Our findings might also be relevant to sustainability Bali's ICH to strengthening the involvement of cultural industry through orange economy activity, in enhancing their place identity and local genius, in supporting and promoting the sustainability ICH of Balinese handwoven textiles. Furthermore, the role of government through cultural policies might also relevant as moderating effect the relationship between orange economy activity and sustainability of ICH.
\end{abstract}

\section{INTRODUCTION}

Sustainability which is often considered a long-term goal and sustainable development, refer to many processes and paths that must be achieved, has developed among academics and policymakers in western countries, and is widely implemented in countries around the world in development policies at the regional level, national and international [1].

More than three decades since the term "sustainability" and "sustainable development" was the primary goal of development since the publication of Our Common Future from U.N., better known as the Brundtland Report. The bestknown definition of sustainable development: "Sustainable development meets the needs of the present without compromising the ability of future generations to meet their own needs" [2]. Before the report was published, which became a milestone of the mobilization of world opinion about environmental problems arising from the impact of development, the idea of sustainability came into public discourse after the publication of the 1972 report, "Limits to Growth" issued by the international think tank Club of Rome. Unfortunately, little attention has been paid to the economic activities of local communities, which are closely related to culture, giving rise to debates about the regeneration of knowledge that has been inherited from generation to generation, their culture, their way of life, and their role in modern development [3].

At present, there has been an interest in the economic field for the values contained in local genius and knowledge [4]. It is said that economic activity that combines cultural approaches and creative economy is one of the sustainable development strategies because it brings economic and cultural dimensions into one holistic framework [5]. However, the literature discussed the sustainability and preservation of traditional cultural industries that have intangible cultural capital is very scarce where most studies focus on the sustainability and preservation of tangible heritage such as the remains of historical buildings or archaeological sites [6-8]. Whereas for many countries, the cultural industry that produces cultural products is a significant unique cultural heritage that is maintained and pursued in serving cultural and economic goals as a sustainable development effort [9-12]. Importance the handicraft industry revealed long before, especially its function in the socio-cultural activities of the community. The intangible cultural heritage (ICH) of handicraft industry such as handwoven textiles faced challenges and constraint contributing to the setback suffered such as lack of availability of sufficient data, industrialization and mass production, regeneration, lack of availability of basic infrastructure, lack of innovation and technology, lack of education, training facilities and financial resources [12]. The challenges also faced by Balinese handwoven textiles (BHT). We revealed that a significant threat to the sustainability of the weaving industry comes from the effect of industrialization from the invasion of imitated mass production textiles from Central Java Province. As a result of industrialization, handwoven textiles are being replaced by machine-made similar items, and competing with comparable alternative 
products. Consequently, handwoven textiles are dwindling in popularity, and traditional crafts face intense competition in marketplaces, where mass-produced things are less expensive and sellers have more manufacturing capacity and logistical assistance.

Furthermore, a lack of regeneration leads to the gradual disappearance of the best weavers, the migration of young people to cities in search of work, and a lack of appreciation for textiles due to the choice of cheaper substitutes as a result of technological sophistication, resulting in less appreciation for textile cultural products.

Researchers have documented the importance of BHT [13, 14]. However, limited studies exploring BHT can support people through their economic activities. The sustainability of BHT implies safeguarding the livelihoods and cultural values of the Balinese people. At a higher level, it has implications for contributing to national integrity, economic prosperity, and heritage value. The sustainability of the Balinese weaving industry requires a shift paradigm in viewing weaving activities as a mechanism in maintaining jobs and livelihoods, especially for rural communities, preserving diverse cultural identities, empowering women, economic progress and social justice. If the weaving industry is allowed to perish, the potential for sustainability of cultural products will also be lost.

This paper will discuss the orange economy, place identity, local genius, cultural policies on the sustainability of ICH through cultural industry based on knowledge passed down from generation to generation. Local genius is a wisdom of traditional culture. Orange economy is a way to turn ideas into cultural products [15]. Handicrafts, for instance, are a way of preserving and promoting cultural and aesthetic intangible cultural heritage, such as numerous traditional craft techniques and abilities handed down through generations [12]. In determining personal identification with the physical environment, place identity is a series of memories, interpretations, thoughts, and emotions [16]. A deep emotional commitment to an individual's unique location or arranged surroundings as self-construction. Furthermore, cultural policies have a significant impact on sustainability of $\mathrm{ICH}$. The orange economy will also be discussed as a mediating variable on place identity and local genius and cultural policies as a moderating variable on the relationship between the orange economy and the sustainability of BHT.

\section{LITERATURE REVIEW}

The United Nations overarching paradigm is sustainable development. The 1987 Bruntland Commission Report defined sustainable development as "development that meets the needs of the present without compromising the ability of future generations to meet their own needs" [2]. Sustainable development has four components - society, environment, culture, and economy - that are inextricably linked, not distinct.

Many scholars emphasize new views and considering the role of culture in sustainable development. Throsby, from a cultural economy point of view with cultural value approach and assessing principles of sustainability [1, 11, 17], the concept of culture-sustainability relationships [18], cultural capital, defined as "traditions and values, heritage and place, art, diversity and social history" [19].

Culturally sustainable development is the idea of development for cultural sustainability, which in essence has an independent role according to the arts and culture and has value in terms of the community itself and culture as a set of attitudes and practices that can play a role in supporting, limiting and or contributing to economic development and social in a broad sense [11].

Culturally sustainable development according to Throsby [1] define in five principles: Intergenerational Equity: action must take a long-term view and not necessarily compromise the capacity of future generations to access cultural resources and meet their cultural needs; this requires special attention to protect and increase the tangible and intangible cultural capital of the country. Intragenerational Equity: development must provide equality in access to cultural production, participation, and enjoyment for all members of society on a fair and nondiscriminatory basis; in particular, attention must be paid to the poorest members of the community to ensure that development is consistent with the goal of poverty alleviation. Importance of Diversity: just as sustainable and environmentally friendly development requires the protection of biodiversity, the value of cultural diversity for economic, social, and cultural development must also be taken into account. Precautionary Principle: when dealing with irreversible consequences such as the destruction of cultural heritage or the extinction of valued cultural practices, a position that avoids risk must be adopted. Interconnectedness: economic, social, cultural, and environmental systems must not be seen separately; instead, a holistic approach is needed, that is, an approach that recognizes the links, especially between economic and cultural development.

\subsection{Place identity}

Traditional handicrafts are inextricably linked to the idea of place [20]. Proshansky et al. [16] defined place identity as a "potpourri of memories, conceptions, interpretations, ideas, and related feelings about specific physical settings as well as types of settings". Place identity also concerns beliefs rooted in experiences that are unconsciously associated with the place. Therefore, it is obvious that the concept of place-identity from Proshansky et al. [16] is a strong emotional attachment to an individual with a particular place or arrangement environment as self construction.

Place identity is often associated with authenticity. An authentic place with a unique and strong character can increase the dignity of the people who live in the place. Furthermore, the authenticity that is reflected in the place identity has a significant effect for cultural-creative economic activity while facing an increasing responsibility to provide welfare and development of local communities [21, 22]. Place identitybased economic development is founded on the notion that a local economy must be established in response to the potential and constraints of that specific location. An authentic and unforgettable experience is inextricably linked to a certain location's distinct local history, environment, and culture [23]. Manenti [24] revealed place identity on enriching the heritage of memory also has a significant influence on sustainability. Barre [25] found meanings of symbolic dimensions linked to place and their relationship to practices that can be formulated into strategies to achieving the goals of sustainability.

Therefore, based on the aforementioned existing literature, the present study of place identity highlights three components: meanings, experiences, and authenticity.

(H1): Place identity has a significant positive effect on the 
orange economy.

(H2): Place identity has a significant positive effect on the cultural sustainability of the BHT.

\subsection{Local genius}

"Wisdom in traditional culture" of ethnic groups is defined as local genius. Local genius encompasses societal norms and values and all aspects of ideas, including those that affect life in the modernization era. The description of local genius with this concept includes a variety of patterns of activity and material cultural results. In a broad sense, local genius is the knowledge or noble values of local cultural assets such as customs and life philosophy [26].

The local genius is essential in absorbing and conducting active selection and processing of external culture and globalization influences. As an expression of experiences life, the local genius is the core of people's cultural life [26]. Therefore, losing spiritual meaning and symbolic meaning might weaken people's emotional power. The intellectual value and emotional ties in a community, both tangible and intangible objects, are unique, determining a place where an item is produced. Cultural products specific to a place, generated by the inherent knowledge, culture, and history, describe particular characteristics of a place. Their preservation will be realized as a result of how cultural products function [27]. Komariah [28] found that local genius has a significant effect on the cultural, environmental, social, and economic of the Ciptagelar community in Java, Indonesia. The local genius of the Ciptagelar community also brings the community's welfare in food security to be independent. The role of local genius in the context of the sustainability of a community is significant because it will determine the nature and form of community culture [29].

Local knowledge passed down from generation to generation as a priceless value for local communities reflects the importance of local genius. Syukur [30] claimed that weaving activities in the Bugis-Wajo community get local genius in the work ethic (reso/pajama) and perseverance (tinulu) as the basis for economic activity and for sustainability. In addition, Lodra [31] argues that economic activity makes Tunun Gringsing textile experience commodification of meaning by weavers, designers, creators but does not abandon the cultural values contained in it. $\mathrm{He}$ believed that commodification has a role in maintaining the sustainability and development of Tunun Gringsing textile. However, its sacredness is still strong, as seen in making Geringsing, materials, motifs, accompanying rituals, ethics, and beliefs.

Indicators of local genius in this study includes orientation as a spiritual belief as a view of life and a system of values as a way of life, characters as the response to the outside world in the context of globalization. Symbolical as patterns and attitudes which embody everyday people's behavior.

(H3): Local genius has a significant positive effect on the orange economy.

(H4): Local genius has a significant positive effect on the cultural sustainability of the Balinese handwoven textiles.

\subsection{Orange economy}

The orange economy is a term to link creative economic activity and cultural economy that transformed through ideas into goods and services which ADB pioneered in 2013 as an alternative in economic and social development [15]. The word orange describes colors that are commonly associated with culture, creativity, and identity. The Sustainable Development Goals (SDGs) were crafted with orange economy in mind, resulting in their inclusion mainly in SDG 8, but also in SDGs 9, 11, 12, and 17 [32].

However, the terms "orange economy" appear in the midst of a debate over the definition of "Creative Cultural Industries (CCI) [15]. The discourse on combining economics and culture is high tense debated, endlessly, and generates various terms $[15,33]$. Such diverse terms have finally emerged, which are understandable because every organization needs to adapt the concept to their policy-making and goals [15].

We adopted the indicator for CCI from Einarson [10] which are consisting of cultural value, capital, innovation, creativity, and intellectual property. Cultural values are considered very important to see the values contained in cultural goods. According to Throsby [11] cultural value has six characteristics: aesthetics, spirituality, social, history, symbolism, and authenticity. Throsby's views of cultural value has been accepted and obtained alternative views, both implicitly and explicitly, in the cultural economics literature [34]. Production of craftmanship has a value as a practice or process has cultural value [34].

Capital is defined as the value of resources that can be used in the production process. Capital can be divided into four variables [10]: First, human capital, which can be explained as individual talent and experience, Human capital is becoming increasingly important in the economy, especially in the creative and cultural industries. Second, social capital which can described by following forms: adherence to social norms, customs, and values, tolerance, an open mind, honesty, indigenous wisdom and knowledge, social network and social leadership, trust, unity, and loyalty, social responsibility, community participation, and independence [35]. In the cultural industry, the community's social network is the main thing for business continuity. Good relationships between individuals and groups have economic potential and can be a good resource when used. Third is natural capital as a resource that can be increased or cannot be increased [10]. Fourth is cultural capital. Natural capital and cultural capital resources are deeply interconnected, and their obligations impose obligations on current and future generations, so it is inappropriate to speak of cultural ecosystems, which support cultural and community life, as well as the natural environment and systems for maintaining continuity. Cultural ecosystems thus denote cultural life and cultural communities.

Creativity is an important concept in CCI which is mostly referred to as an innovative concept and a driving force in technological progress [10]. A frequent use of the term "creativity" is a generalization of the idea that is part of innovation, where innovation is usually characterized as the implementation of the idea. However, creativity includes new knowledge, while innovation may not be synonymous with creativity and is additional [36].

Innovation can be broadly thought of as new ideas, new ways of looking at things, new methods, or products that have value $[10,36]$. Innovation contains the idea of output, of actually producing or doing something different, making something happen or implementing something new. Imagination is the initial stage of the creative process. This stage will bring up new ideas so that they will be of high quality when they are brought to the communal/organizational group. It doesn't just stop at the process of having new ideas 
or ideas; they must be organized into an integrated whole so that they have value. Kerr [37] argues that creativity is ultimately the basis for the development of human capital and is an important root of the dynamics of the economic system. When these factors influence each other and interact, which leads to creativity when combined, On the individual side of a process of imagination, organization, and taste, there are other factors that also play an influential role, such as environmental and community factors in which creative work is carried out. Viewed from that broad perspective, the influence of the emergence of creativity appears as a social system or process that depends on the environment of the creator $[10,11]$.

In the protection of cultural-creative products, products created from original ideas in the orange economy, of course, point to copyright protection inherent in creators [10, 36, 38].

Introducing culture in the economic development agenda by recognizing the economic potential of the orange economy is one of the practical strategies carried out in the sustainability strategy by developing and fostering arts, crafts, and cultural activities and a broad and solid foundation. The concept of the orange economy expects to provide a new approach to appreciating the work of creators and artists in generating significant levels of tangible and intangible cultural capital. In summarizing the literature review, creative and cultural economies have various characters constructed from multiple multidisciplinary components and interactions.

CCI such as handicrafts are means to preserve and promote cultural and artistic traditions, such as various traditional craft techniques and skills passed down from generation to generation [12]. At the same time, cultural goods produced in the orange economy have economic potential where their relationship with culture from traditional knowledge, which is used as an essential feature, in a chain of relationships, from production ending to final consumption, there is a relationship with cultural and economic goals in the sustainable development [5]. It further facilitates sustainable development in peripheral and rural regions that possess limited financial resources and are negatively affected by the outward migration of human capital.

CCI that have authentic characteristics are an essential basis for any socio-economic development, so that the concept of place-based cultural industries is a unique feature that provides a link between generations, connecting the past, present, and future that able to develop in line with changes in the sustainable environment. If the mediating effect of orange economy is significant, local genius and place identity may indirectly affect cultural sustainability, even if it does not directly affect cultural sustainability. In addition, the effect of local genius and place identity on cultural sustainability will be further enhanced through the mediating effect of orange economy.

(H5): Orange economy has a significant positive effect on the cultural sustainability of the Balinese handwoven textiles.

(H6): Orange economy variable mediates the relationship between place identity and cultural sustainability of the Balinese handwoven textiles.

(H7): Orange economy variable mediates the relationship between local genius and cultural sustainability of the Balinese handwoven textiles.

\subsection{Policy}

The cultural industry can be a prime target for policies that lead to economically and culturally sustainable development that can generate significant long-term economic, social, cultural, and environmental benefits [39]. Citizen participation in cultural life enhances social cohesion and community empowerment. Government activities, laws, protect, inspire, and economically support activities related to the arts and creative sectors are referred to as cultural policy, whereas culture can include activities related to language, heritage, and diversity [40].

A clearly defined concept of cultural capital, with a clear delineation of its value in terms of culture and economy, can help sharpen the process of implementing appropriate policies to be designed and implemented [11]. Without the government's role reflected in the public policies taken, the big goals in economic development will not be maximally achieved. Other purposes such as preserving cultural heritage and the sustainability of local communities must be considered so that community welfare can be realized. A critical sentence to examine the relationship between government policies in the context of cultural and economic policies from David Throsby [41] is that current cultural policies require a better or holistic understanding of the complex interrelationships between economy and culture.

Government policies are a driving factor for cultural economic activity as a sustainability effort. In this research there are three polices regarding culture sustainability. First is Indonesia law no 5 of 2017 (UU Republik Indonesia No 05 Tahun 2017) concerning the advancement of culture. The policy for the advancement of culture was chosen taking into account a number of documents on the cultural system. There are two documents that become the main reference. First, the Law Number 11 of 2010 (UU No 11 Tahun 2010) concerning Cultural Conservation. Second, the Convention for the Safeguarding of the ICH which was formulated by UNESCO in 2003. The document focuses on intangible culture which includes oral traditions and expressions as well as traditional craft skills. There are four points of the policy; protection, development, educations, and utilization.

Second and third, two policies from the provincial government of Bali specifically issued a policy regading handwoven textiles. First policy is the regulation of the governor of bali number 79 of 2018 (Pergub No 79 Tahun 2018) concerning days of use of bali traditional clothes and circular letter of the governor of bali number 04 of 2021 (SE Gubernur Bali No 04 Tahun 2021) concerning the use of Balinese handwoven textiles in a certain day.

Einarsson [10] stated that currently much attention is paid to analyzing the impact of economic factors on various matters relating to cultural goods, cultural industries and cultural policies. The results of these analyzes are then often aggregated to support arguments for public support for culture, which will usually have a significant influence on public policy discourse and thus influence government behavior in paying attention to culture. Cultural analysis in economic development is concerned with the contribution of art and culture to the economy, the study of impact, cultural diversity, and sustainability.

Based on the aforementioned existing literature and policies, the present study highlights the perception of Balinese handwoven textiles cultural industry about the cultural policies. The cultural policies has an direct impact to sustainability and also moderates the relationship between orange economy and sustainability. We propose the following hypothesis: 
(H8): Cultural policies has a significant positive effect on the cultural sustainability of the Balinese handwoven textiles

(H9): Cultural policies moderates the relationship between the orange economy and cultural sustainability of the Balinese handwoven textiles

\subsection{Conceptual framework}

As discussed, this paper developed a conceptual framework of the relationship between place identity, local genius, orange economy, cultural policies and sustainability. This explained that perceived place identity and local genius positively impact the perceived orange economy and a positive impact on perceived sustainability intangible heritage of Balinese handwoven textiles. The orange economy has mediated the relationship between place identity and local genius to the perceived sustainability intangible heritage of Balinese handwoven textiles. Additionally, perceived cultural policy positively influences to perceived sustainability intangible heritage of Balinese handwoven textiles. It has a moderate effect on the relationship between the orange economy and the perceived sustainability intangible heritage of Balinese handwoven textiles. The variables are clarified by conceptual model and research hypotheses, as shown in Figure 1.

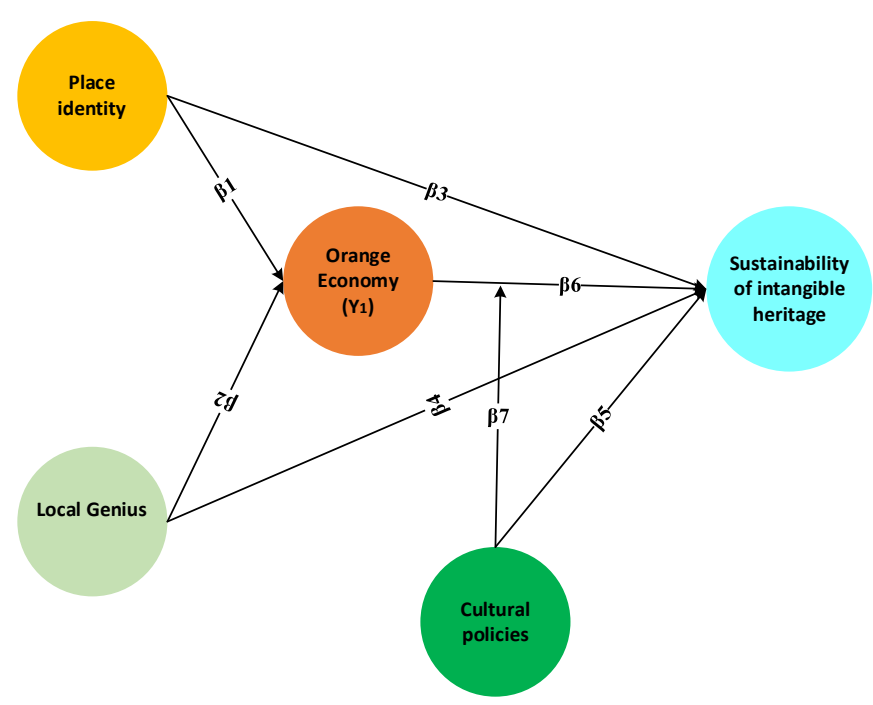

Figure 1. Conceptual model and hypotheses

\section{METHODS}

\subsection{Study area}

Bali Province, Indonesia was selected as the target area for this study. Indonesia is comprised of 34 provinces, is the fourth most populous country in the world. Indonesia's population based on the 2020 population census is 270.20 million people with 633 ethnic groups. Islam is the largest religion in Indonesia, with 86.88 percent of the Indonesian population identifying themselves as Islam. Bali is an island that has survived the influence of Islam that spread and ruled the island of Java since the 15th century. Bali with a population of 3,89 million people, 82 percent are Hindus who continue to practice a belief system based on Balinese Hinduism cosmology and its view of the universe by combining ancestor worship which has a deep influence on society.

\subsection{Data collection}

Data collection was carried out using survey technique to 197 people from community of handwoven textiles cultural industry in Bali based on Bali's industry and trade office data 2019. However, after we conducted field research, only 145 weaving cultural industries were found in the province of Bali. We used case survey to collect the information from a of community. Genuine data can be a powerful stimulant for local problem solving. It frequently serves as a directive for decision-makers who must make difficult decisions. From the data survey, information obtained 37.24 percent weavers are in the age range between 41-50 years. In more detail, the age distribution of respondents is presented in Table 1 .

Table 1. Age distributions characteristic of the respondents

\begin{tabular}{cccc}
\hline \multirow{2}{*}{ No } & \multirow{2}{*}{ Age } & \multicolumn{2}{c}{ Frequency } \\
\cline { 3 - 4 } & & (people) & $(\%)$ \\
\hline 1 & $\leq 25$ & 2 & 1.37 \\
2 & $26-30$ & 3 & 2.06 \\
3 & $31-35$ & 11 & 7.58 \\
4 & $36-40$ & 13 & 8.96 \\
5 & $41-45$ & 26 & 17.93 \\
6 & $46-50$ & 28 & 19.31 \\
7 & $51-55$ & 14 & 9.65 \\
8 & $56-60$ & 23 & 15.86 \\
9 & $61-65$ & 11 & 7.58 \\
10 & $66-70$ & 8 & 5.51 \\
11 & $>70$ & 6 & 4.13 \\
\hline \multicolumn{2}{c}{ Total } & 145 & 100 \\
\hline
\end{tabular}

Furthermore, the highest number of workers in the handloom textile cultural industry are women at 89 percent and men only 11 percent. From these data, it can be explained that the role of women in the sustainability of knowledge on weaving cultural intangible heritage is very important. Weaving is a spiritual practice that requires patience and high accuracy in producing noble cultural products.

\subsection{Measures}

We constructed a structured questionnaires specifically designed to obtain quantitative data needed to determine respondent perceptions. The respondents were asked the questionnaires by surveyors with a form containing 32 questions to the weaving cultural industry in Bali province. The questionnaires are divided into three parts. The first is a 6-part filter question, a 32-part classification question, and a scale part. The questionnaire format using 7-point Linkert scale ranging from 1 (strongly disagree) to 7 (strongly agree). The use of a 7-point scale offers high reliability, a low percentage of undecided responses, and ease of discrimination (for respondents) between the values of the scale.

\subsection{Analytical method data}

Variance based structural equation modelling was performed using Partial Least Squares Structural Equation Modelling (PLS-SEM): that measurement and structural model were run stimulatory using SmartPLS 3. The statistical data analysis program aims to see the relationship between variables through three stages. First, the evaluation stage of the measurement model, the second stage of the assessment of the structural model, and the third stage of hypothesis testing with bootstrapping procedures for testing hypothesis looking at the 
direct relationship between variables, the effect of mediation, and moderation.

PLS-SEM is appropriate for this investigation for some arguments. First, PLS is appropriate when metrics are not properly defined. As a result, PLS is acceptable in this study because some items have been revised and are being used in a new context. Second, PLS enables simultaneous measurement and theory investigation. therefore, PLS is suited for this investigation since the goal was to concurrently analyze measurement qualities (outer-measurement model) and test hypotheses (inner-structural model). Third, compared to covariance-based SEM, PLS is said to be more easily allowing the use of formative indicators. PLS is suitable for the investigation of relationships in a predictive rather than a confirmatory fashion. Thus, PLS is appropriate in this study as maximizing the prediction of respective constructs was a priority.

\section{RESULTS}

Based on the survey results, from an urban and rural perspective, there is a big difference where 97 percent of the weaving culture industry in Bali is in rural areas. In more detail the distribution of Balinese handwoven textiles culture industry in Bali Province, the Figure 2 is presented the largest handwoven cultural industry is in the Klungkung Regency at 48 percent. In the second place, Karangasem Regency is 26 percent, and the third is Gianyar Regency 8 percent. While Bangli Regency only 1 percent, Tabanan Regency 0 percent, Badung Regency 3 percent, Denpasar City 3 percent, and Buleleng Regency 4 percent.

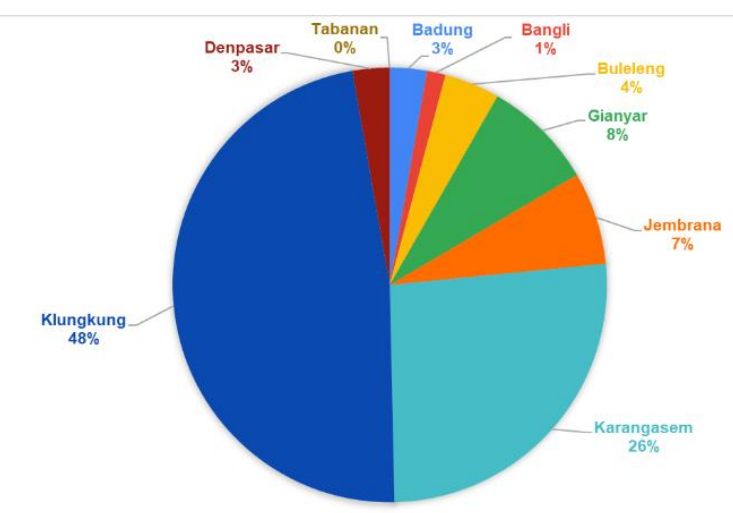

Figure 2. Distribution of Balinese weaving culture industry in Bali province 2021

Table 2. Reliability and validity test for the complete data

\begin{tabular}{|c|c|c|c|c|c|}
\hline Constructs & Item & Outer Loadings & Cronbach's $\alpha$ & $\mathbf{C R}$ & AVE \\
\hline \multirow{22}{*}{ Orange Economy } & Orange Economy (O.E.) & - & 0.991 & 0.992 & 0.883 \\
\hline & Symbolic value (OE1.1) & 0.931 & & & \\
\hline & Aesthetic value (OE1.2) & 0.960 & & & \\
\hline & Historical value (OE1.3) & 0.941 & & & \\
\hline & Social value (OE1.4) & 0.954 & & & \\
\hline & Authenticity value (OE1.5) & 0.945 & & & \\
\hline & Spiritual value (OE1.6) & 0.944 & & & \\
\hline & Production value (OE1.7) & 0.955 & & & \\
\hline & Social capital (OE2.1) & 0.950 & & & \\
\hline & Human capital (OE2.2) & 0.953 & & & \\
\hline & Cultural capital (OE2.3) & 0.962 & & & \\
\hline & Nature capital (OE2.4) & 0.955 & & & \\
\hline & technology utilization (OE3.1) & 0.968 & & & \\
\hline & New method (OE3.2) & 0.968 & & & \\
\hline & Imagination (OE4.1) & 0.976 & & & \\
\hline & Social-environmental support (OE4.2) & 0.975 & & & \\
\hline & Communal intellectual right (OE5.1) & 1.000 & & & \\
\hline & Value (OE.1) & 0.993 & 0.981 & 0.984 & 0.897 \\
\hline & Capital (OE.2) & 0.988 & 0.968 & 0.977 & 0.912 \\
\hline & Innovation (OE.3) & 0.957 & 0.949 & 0.975 & 0.951 \\
\hline & Creativity (OE.4) & 0.965 & 0.933 & 0.968 & 0.937 \\
\hline & Communal intellectual property right (OE. .5 & 0.939 & 1.000 & 1.000 & 1.000 \\
\hline \multirow{3}{*}{ Place Identity } & Meanings (PI.1) & 0.926 & & & \\
\hline & Authenticity (PI.2) & 0.929 & 0.936 & 0.959 & 0.886 \\
\hline & Experience (PI.3) & 0.965 & & & \\
\hline \multirow{3}{*}{ Local Genius } & Way of Life (LG.1) & 0.947 & & & \\
\hline & Character (LG.2) & 0.947 & 0.948 & 0.967 & 0.907 \\
\hline & Symbolic (LG.3) & 0.963 & & & \\
\hline \multirow{4}{*}{ Cultural Policies } & Development (PP.1) & 0.968 & & & \\
\hline & Protection (PP.2) & 0.953 & 0.977 & 0.982 & 0.917 \\
\hline & Utilization (PP.3) & 0.962 & & & \\
\hline & Education (PP.4) & 0.946 & & & \\
\hline \multirow{5}{*}{ Cultural Sustainability } & Intergenerational equity (SWCI.1) & 0.941 & \multirow{5}{*}{0.976} & \multirow{5}{*}{0.981} & \multirow{5}{*}{0.912} \\
\hline & Intragenerational equity (SWCI.2) & 0.952 & & & \\
\hline & Importance of diversity (SWCI.3) & 0.963 & & & \\
\hline & Precautionary Principle (SWCI.4) & 0.958 & & & \\
\hline & Interconnectedness (SWCI.5) & 0.960 & & & \\
\hline
\end{tabular}


The result is following the findings by Fahmi [42] that 75 percent of the traditional culture industry in Indonesia, namely on the islands of Java and Bali, has existed for several generations where the knowledge and skills possessed are passed down from generation to generation, which are mostly found in remote or rural areas. Cultural products produced by the traditional cultural industry are a source of livelihood for local communities and are linked to other sectors such as tourism.

\subsection{Measure validity}

Table 2 outlines the factor loadings, composite reliability (CR), and average variance (AVE) extracted derived from PLS analysis to evaluate the research model. All constructs and first-order constructs (as reflective of the orange economy variable) have outer loading above 0.7 and AVE above 0.50 . AVE was higher than the suggested level of 0.50 , and all item factor loading was higher than the recommended level of 0.50 , providing strong evidence of convergent validity. All constructs composite reliabilities (CR) were likewise larger than the threshold benchmark of 0.70 criterion, indicating that our measurements were reliable.

In testing the PLS structural model, it can be evaluated using the R-square value for the dependent variable and its significance value based on the t-values in each path [43]. After the model meets the criteria for testing the outer model, the next step is testing the inner model. Testing on the inner model means that the relationship between latent variables will be seen by looking at the estimation results from the bootstrapping results on the path coefficient and a significance level of 0.05 .

Table 3. R-square

\begin{tabular}{ccc}
\hline Variable & $\boldsymbol{R}$-Square & Fit Level \\
\hline Orange economy & 0.582 & large \\
Cultural Sustainability & 0.870 & large \\
\hline
\end{tabular}

Table 3 shows that the R-square value in the orange economy construct is 0.582 . This means that the variability of the orange economy construct can be explained by the construct of local genius and place identity by 58.2 percent. The remaining 41.2 percent is explained by factors other than these three variables. Furthermore, the cultural industry sustainability construct has an R-Square value of 0.870 which means that 87 percent of the variability of the cultural sustainability construct can be explained by cultural policies, orange economy, local genius, and place identity. The remaining 13 percent is explained by factors other than the five.

Furthermore, based on the R-square results in Table 6, it can be calculated Q2 or Stone Geiser Q-Square test, namely:

$\mathrm{Q}^{2}=1-\{(1-0.870)(1-0.582)\}$

$$
=1-\{(0.130)(0.418\}
$$$$
=0.987
$$

The result of the $\mathrm{Q}^{2}$ calculation is 0.987 means high predictive prevalence, so the resulting model is suitable for predicting. The result can be interpreted that variations of the cultural sustainability variable 98.7 percent can be explained by variables orange economy, cultural policies, local genius and place identity, while remaining 1.3 percent is explained the other variables outside the model.

\subsection{Hypothesis testing and inferential statistic}

In explaining the relationship between research variables, namely latent variables in SEM-PLS, it can be seen through the analysis of direct influence, direct influence with the moderator, indirect influence, and total effect. To find out the direct influence between construct variables, it can be seen from the analysis results of the path coefficients values shown in Figure 3.

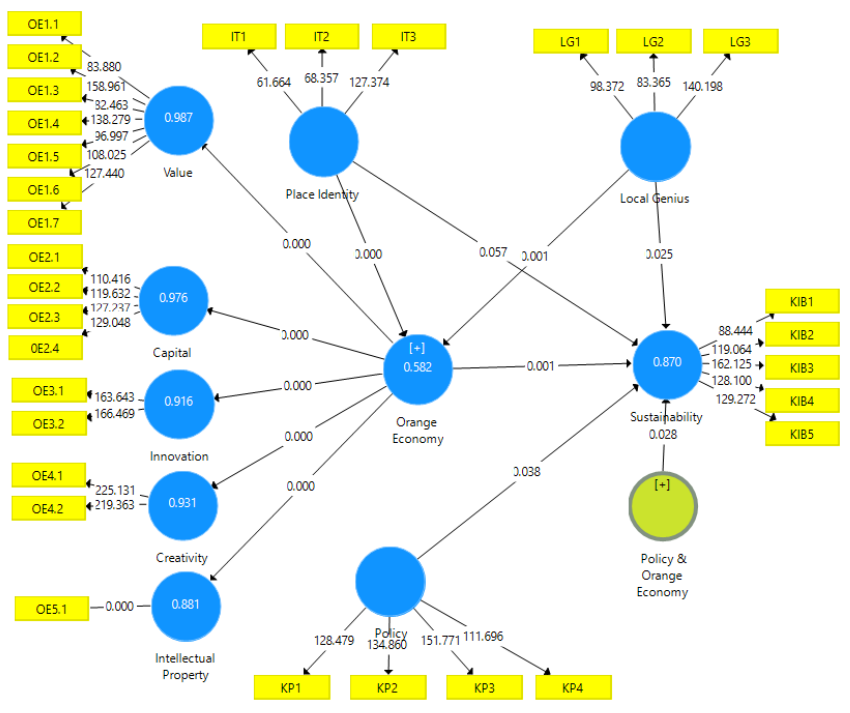

Figure 3. Diagram of PLS algorithm

Furthermore, the analysis results of the path coefficients values shown in Table 4

Table 4. Path coefficient direct effect

\begin{tabular}{ccccccc}
\hline $\begin{array}{c}\text { Hypothesized } \\
\text { Relationship }\end{array}$ & $\begin{array}{c}\text { Original } \\
\text { Sample (O) }\end{array}$ & $\begin{array}{c}\text { Sample Mean } \\
(\mathbf{M})\end{array}$ & $\begin{array}{c}\text { Standard Deviation } \\
(\text { STDEV) }\end{array}$ & $\begin{array}{c}\text { T Statistics } \\
(\mid \mathbf{O} / \text { STDEV })\end{array}$ & P Values & Information \\
\hline LG $\rightarrow$ OE & 0.413 & 0.414 & 0.136 & 3.037 & 0.001 & Supported \\
LG $\rightarrow$ CS & 0.236 & 0.241 & 0.121 & 1.916 & 0.025 & Supported \\
PI $\rightarrow$ OE & 0.427 & 0.425 & 0.125 & 3.405 & 0.000 & Supported \\
PI $\rightarrow$ CS & 0.127 & 0.118 & 0.080 & 1.586 & 0.057 & Not Supported \\
OE $\rightarrow$ CS & 0.529 & 0.516 & 0.161 & 3.283 & 0.001 & Supported \\
CP $\rightarrow$ CS & 0.274 & 0.257 & 0.154 & 1.995 & 0.038 & Supported \\
CP*OE $\rightarrow$ CS & 0.146 & 0.120 & 0.076 & 3.072 & 0.028 & Quasi \\
Moderation \\
\hline
\end{tabular}

Noted: Orange Economy (OE), Place Identity (PI), Local Genius (LG), Cultural Policies (CP), Cultural Sustainability (CS). 
Table 5. Path coefficient indirect effect

\begin{tabular}{ccccc}
\hline Hypothesized Relationship & Original Sample & T Statistics & P Values & Information \\
\hline LG $\rightarrow$ OE $\rightarrow$ CS & 0.218 & 2.104 & 0.018 & Partial Mediation \\
PI $\rightarrow$ OE $\rightarrow$ CS & 0.226 & 2.360 & 0.009 & Full Mediation \\
\hline Noted: Orange Economy (OE), Place Identity (PI), Local Genius (LG), Cultural Sustainability (CS).
\end{tabular}

Table 4 shows that more details hypothesis test are explained as follows:

1. The hypothesis one $(\mathrm{H} 1)$, the regression coefficient of the influence of place identity on the orange economy is 0.427 at the sig level of 0.05 with a P-value of 0.000 (P-value $<0.05)$. It can be stated that the place identity hypothesis directly has a positive and significant effect on the orange economy is accepted.

2. The hypothesis two $(\mathrm{H} 2)$, the regression coefficient of the influence of place identity on the cultural sustainability is 0.127 at the sig level of 0.05 with a P-value of 0.057 (Pvalue $<0.05)$. It can be stated that the place identity hypothesis directly has a positive and non-significant effect on the cultural sustainability of Balinese handwoven textiles is not accepted.

3. Local genius also has a direct positive and significant effect on the orange economy ( $\mathrm{H} 3$ accepted) as indicated by the regression coefficient of the influence of local genius on the orange economy is 0.413 at the sig level of 0.05 with a $\mathrm{P}$-value of 0.001 ( $\mathrm{P}$-value $<0.05$ ).

4. Meanwhile, the local genius regression coefficient on the sustainability of the culture industry is 0,236 at the sig level of 0.05 with a P-value of 0.025 (P-value <0.05). It can be stated that the fourth hypothesis $(\mathrm{H} 4)$ of local genius directly has a positive and significant effect on the cultural sustainability of Balinese handwoven textiles.

5. Orange economy regression coefficient on the sustainability of the culture industry is 0.529 at the sig level of 0.05 with a P-value of 0.001 (P-value $<0.05$ ). It can be stated that the fifth hypothesis (H5) of orange economy directly has a positive and significant effect on the cultural sustainability of Balinese handwoven textiles.

Furthermore, to find out the moderation effect between construct variables, it can be seen from the analysis results of the path coefficients values shown in Table 5.

6. Orange economy variable has the full mediation the relationship between place identity and the cultural sustainability of the Balinese handwoven textiles. This can be seen from the place identity variable that has a direct and insignificant effect on the sustainability of the cultural industry, the orange economy has a significant influence on the sustainability of the cultural industry, and the place identity variable has an indirect influence on the cultural sustainability of Balinese handwoven textiles through the orange economy variable. The regression coefficient of the indirect influence of place identity on the cultural sustainability through the orange economy is 0.218 at the sig level of 0.05 with a P-value of 0.009 (P-value $<0,05)$. It can be stated that the place identity indirectly has a positive and significant effect on the sustainability of the cultural industry through the orange economy (H6 supported).

7. Meanwhile, in mediating the influence of local genius and the sustainability of the Balinese weaving industry, the orange economy has a partial mediation nature. This is seen from the local genius variable. The orange economy has a significant direct influence, and the local genius variable indirectly influences the sustainability of the cultural industry through the orange economy variable. The regression coefficient for the indirect effect of local genius on the sustainability of the cultural industry through the orange economy is 0.226 at the sig level of 0.05 with a $\mathrm{P}$-value of 0.018 (P-value $<0.05)$, which means that hypothesis seven $(\mathrm{H} 7)$ is supported.

8. Cultural policies has a direct positive and significant effect on the cultural sustainability (H8 accepted) as indicated by the regression coefficient of the influence cultural policies is 0.274 at the sig level of 0.05 with a P-value of 0.038 (Pvalue $<0.05$ ).

9. Ensuring the role of cultural policies is statistically analysed using a model of moderation. Cultural policies in this case is measured by protection, development, educations, and utilization variables that can moderate (reinforce) the influence of cultural sustainability. Cultural policies have significant effect on the cultural sustainability $(0.023<0.05)$ and moderation effect of cultural policies is significant $(0.001<0.05)$, which means the hypothesis nine (H9) is supported. The results can explain that cultural policies as quasi-moderation means cultural policies variable significant as a direct variable to cultural sustainability and also significant as a moderate variable of the relationship orange economy with cultural sustainability of the Balinese handwoven textiles.

\section{DISCUSSION}

This study investigates the factors that influence the cultural sustainability of BHT after identifying the research opportunities through phenomena and literature reviews. The research and statistical analysis resulted in several significant findings that provide crucial insights into the cultural sustainability of BHT.

The result of this study concluded that there is an influence of place identity on orange economy. Its indicates that the more positive place identity such as the meaning of Balinese handwoven fabrics in the form of connectivity between physical, place, culture, and emotion, highlighting the characteristics of a place, and highlighting the experience aspect of sense of place that brings memories to create feelings, then will be able to increase the activity of the orange economy activity. This result support the previous studies from ref [44]. In the BHT cultural industry, the identity of the place is strongly attached to areas that have the potential for woven fabrics that have economic potential so as to provide welfare for the local community. The cultural industry shows to bring out the value of the authenticity of the place as a strength of cultural products. For example, Tenganan Pegringsingan Village has authentic textiles called Tunun Gringsing, which are produced by the double ikat technique as an economic source for the Tengananese people. In addition, the authentic Cepuk textiles from the Nusa Penida Island which must be present at every Yadnya ritual in Bali is an economic source for local residents.

The findings of this study show that local genius which are 
the three principle of Balinese Hinduism framework of Balinese people - Tattwa means belief, Susila means ethics, Upacara means ritual, has a significant positive influence on orange economy. It indicates the more positive local genius implemented by Balinese people, which is reflected in the spiritual aspect, namely the orientation that shows the view of life and the system of community values, the character aspect, namely the ability to accommodate external cultural elements and ways of life in people's lives, and the symbolic aspect of cultural elements that have a meaning in the view of life. passed down from generation to generation, the more it is able to increase the activity of the orange economy. This finding explicitly supported previous research by ref. [27, 45, 46]. Tattwa is the essence or truth or belief that determines behavior in dealing with worldly problems, which is reflected in the philosophy of the Balinese Hindu community in embracing the concept of Tri Hita Karana. Morals or ethics are applied in the social structure of society. The variety of Balinese handwoven textiles is due to the use-value and association value used in five categories of ceremonies to perform by Balinese called Panca Yadnya. The Panca Yadnya in Bali also makes the local community's economy live and grow. The development of the times and modernization resulted in various types of businesses appearing due to Panca Yadnya. The persistence of the local genius of the Balinese people will result in economic activities based on cultural values that will continue to exist and increase. The character and symbolic value in cultural products produced has a spiritual function that the current generation uses to earn income through economic activities by the community.

Furthermore, the findings of this study show that local genius also has a significant positive influence on cultural sustainability. It indicates that the more positive local genius implemented by Balinese people, the more it is able to increase cultural sustainability. This study supports the findings ref. [28, $47,48]$. These results can be interpreted in the context of local genius, which is reflected by the character of the Balinese people who still hold fast to the principles of Hinduism, making Balinese woven fabrics have symbolic and spiritual functions in religious and cultural activities, thus making the Balinese weaving industry continue. The development of the era and the times did not change the value of the divine woven fabric of Bali because of the flexibility of the cultural values of the Balinese people. In Tenganan Pegringsingan, for example, Gringsing textiles is closely related to ceremony in Bali so the need for textiles continues for ceremonial needs.

The meditation test found the orange economy mediate the relationship between local genius and the cultural sustainability of Balinese handwoven textiles. This study reveals Balinese handwoven textiles have economic benefits to the local community through orange economy activity to fulfilling spiritual needs and community identity. The orange economy in the demand and supply of cultural goods produced to be used according to its evolving of the functions, making Balinese handwoven textiles sustainable. Local genius as a basic personality is essential because it determines the form of community culture that is developing to be able to process natural resources and knowledge and absorb cultural influences that come from outside the region, which are then absorbed, selected, and managed.

The results of the second mediation test revealed that the orange economy mediates the relationship between place identity and cultural sustainability. This finding supports the opinion of Vecco et al. [27], where cultural products that are specific to a place, which generated by the inherent knowledge, culture, and history, describe specific characteristics of a place, and sustainability will be realized as a result of how cultural products function. This finding shows that when a person's "feel" of the identity of a place increases through people's consumption behavior towards woven textiles, then the orange economy through the production behavior of the cultural industry has a positive impact on the cultural sustainability of Balinese handwoven textiles.

The findings of this study show that cultural policies has a positive and significant influence on cultural sustainability. It indicates that the more positive cultural policies implemented which are consisting of cultural industry development, regulatory infrastructure, innovation development policies, market development and expansion as well as education and training, the more it is able to increase cultural sustainability of BHT. The findings supports ref. [49, 50]. Furthermore, the moderation test reveal that cultural policies moderate the relationship between the orange economy and cultural sustainability of Balinese handwoven textiles. The role of the cultural policies from government of Bali regarding cultural sustainability of the Balinese handwoven textiles through cultural industry can also be seen through the regulation No. 79 of 2018 concerning the day of use of Balinese traditional clothing and No. 04 of 2021 in section C point 1, which supports cultural diversity by respecting and preserving the cultural heritage of Balinese endek textile and others BHT in supporting the cultural sustainability. From the perspective of the handwoven textiles craftwoman Dewa Ayu from Pelangi handwoven endek textile in Sidemen village, the policies have a significant impact on the demand for woven fabrics.

.....fortunately, in this pandemic Covid-19, the government established the policy on using Balinese handwoven textiles implemented to the public, especially to civil servants, students, private sectors workers in Bali. This policy is very impactful and beneficial for us directly; this then opens wider public attention to us (interviewed Dewa Ayu, 15 July 2021).

\section{CONCLUSION}

Based on our findings, this study shows following contributions. There is a significant positive influence of place identity toward orange economy activity. Therefore, the more place identity increases, the more it can improve orange economy activity. There is a significant positive influence of local genius toward orange economy activity. Therefore, the more local genius increases, the more it can improve orange economy activity.

Furthermore, there are significant positive influence of orange economy, local genius and cultural policies toward sustainability of the BHT. This means that the more orange economy increases, it can improve sustainability of BHT. This result strengthens the research finding that the economic motivation is the main purpose to sustaining the practice the knowledge and weaving skills that have been passed down from generation to generation as a source of community welfare. On the other hand, place identity is unable to strengthen the sustainability of the BHT.

The orange economy is able to mediates the relationship between place identity and local genius on sustainability of the BHT. The cultural industry sector is one possible alternative model for economic diversification and growth in developing country which have cultural, and physical characteristics and 
levels of economic development. It is related to the characteristics of the data obtained in this study that the cultural industry existed for several generations where the knowledge and skills possessed are passed down from generation to generation, which are mostly found 97 percent located in rural areas. Orange economy activity in cultural industry such as handicrafts are a means to sustaining and promote cultural and artistic traditions, such as various traditional craft techniques and skills that are passed down from generation to generation.

There is significant positive influence of cultural policies toward sustainability of BHT. Cultural polices also moderate the relationship between the orange economy activity and sustainability of BHT. To archives the cultural sustainability from policies, the local government should prioritize development, education, utilization, and protection regulation of ICH. It is also important for local governments to increase education and development policies to reach the younger generation's attention to improve the social value and hold cultural product exhibitions to reach a broader market.

This research finds the regeneration process, which is a challenge to think about and find solutions on how to get young people to practice weave by including the knowledge weaving as the local subject in an education program. Consequently, local governments need to examine administrative and political factors to enhance the younger generation's enthusiasm for the knowledge and cultural product.

Understanding sustainability will enable increased economic activity, strengthening local genius for the sustainability of Balinese handwoven textiles. By gathering perception data from the survey, this study narrows the research target and enhances the appropriateness with the study's objective. Furthermore, the cultural policies can encourage consumption in increasing production and protection of handwoven textiles to grow awareness of cultural sustainability.

\section{ACKNOWLEDGMENT}

The authors would like to sincerely thank all weavers' communities in Bali especially the weavers community in Sidemen Village, weavers community Gelgel Village, weavers community Tenganan Pegringsingan Village, Pertenunan Putri Mas Jembrana, Ida Ayu Ngurah Puniari, Anom Mayun, who helped in the successful completion of this study.

\section{REFERENCES}

[1] Throsby, D. (2017). Culturally sustainable development: theoretical concept or practical policy instrument? International Journal of Cultural Policy, 23(2): 133-147. https://doi.org/10.1080/10286632.2017.1280788

[2] WCED. (1987). WCED (World Commission on Environment and Development) Our Common Future. In Oxford: Oxford University Press.

[3] Throsby, D., Petetskaya, E. (2016). Sustainability concepts in indigenous and non-indigenous cultures. International Journal of Cultural Property, 23(2): 119140. https://doi.org/10.1017/S0940739116000084

[4] Davis, S.H., Ebbe, K. (1993). Traditional knowledge and sustainable development. Traditional Knowledge and
Sustainable Development,

http://search.iisd.org/pdf/2007/igsd_traditional_knowled ge.pdf\%5Cnhttp://www.iisd.org/pdf/2007/igsd_tradition al_knowledge.pdf.

[5] Yang, J., Černevičiūtè, J. (2017). Cultural and creative industries (CCI) and sustainable development: China's Cultural Industries Clusters, 5(2): 231-242. http://doi.org/10.9770/jesi.2017.5.2(6)

[6] Hou, J., Chan, E.H.W. (2017). Policy approaches for sustainable conservation of built heritage using transfer of development rights: International comparison. Sustainable Development, 25(6): 528-545. https://doi.org/10.1002/sd.1676

[7] Nocca, F. (2017). The role of cultural heritage in sustainable development: Multidimensional indicators as decision-making tool. Sustainability (Switzerland), 9(10). https://doi.org/10.3390/su9101882

[8] Rolfe, J., Windle, J. (2003). Valuing the protection of aboriginal cultural heritage sites. Economic Record, 79(SPECIAL ISSUE), 79: 85-95. https://doi.org/10.1111/1475-4932.00094

[9] Černevičiūtè, J., Strazdas, R., Kregždaitė, R., Tvaronavičienè, M. (2019). Cultural and creative industries for sustainable postindustrial regional development: The case of Lithuania. Journal of International Studies, 12(2): 285-298. https://doi.org/10.14254/2071-8330.2019/12-2/18

[10] Einarsson, Á. (2016). Cultural Economics. In Bifröst University. Bifröst University.

[11] Jaya Aziz, I. (2001). Economics and culture. Buletin Ekonomi Moneter Dan Perbankan, 22(1): 282-302. https://doi.org/10.21098/bemp.v22i1.1035

[12] Yang, Y., Shafi, M., Song, X., Yang, R. (2018). Preservation of cultural heritage embodied in traditional crafts in the developing countries. A case study of Pakistani handicraft industry. Sustainability (Switzerland), 10(5): 1336. https://doi.org/10.3390/su10051336

[13] Ramseyer, U. (1984). Clothing, Ritual and Society in Tenganan Pegeringsingan (Bali). In Naturforschenden Gesellschaft, Basel.

[14] Nabholz-Kartaschoff, M.L. (1997). Cepuk: Sacred Textiles from Bali and Nusa Penida. In Balinese Textiles, pp. 95-114.

[15] Buitrago, F., Duque, I. (2013). The Orange Economy. Inter-American Development Bank 1300 New York Avenue NW Washington, DC 20577.

[16] Proshansky, H.M., Fabian, K.A., Kaminoff, R. (1983). Place-identity: Physical world socialization of the self. Journal of Environmental Psychology, 3(1): 57-83. https://doi.org/10.1016/S0272-4944(83)80021-8

[17] Throsby, D. (1999). Cultural capital. Journal of Cultural Economics, 23(1-2): 3-12. https://doi.org/10.1023/A:1007543313370

[18] Soini, K., Dessein, J. (2016). Culture-sustainability relation: Towards a conceptual framework. $\begin{array}{llll}\text { Sustainability } & \text { (Switzerland), } & 8(2): & \end{array}$ https://doi.org/10.3390/su8020167

[19] Duxbury, N., Gillette, E. (2007). Culture as a Key dimension of sustainability: Exploring concepts, themes, and models. Vancouver, British Columbia: Creative City Network of Canada - Centre of Expertise on Culture and Communities.

[20] Zhang, X., Li, Y., Lin, J., Ye, Y. (2021). The construction 
of placeness in traditional handicraft heritage sites: A case study of suzhou embroidery. Sustainability (Switzerland), 13(16): 9176 https://doi.org/10.3390/su13169176

[21] Maha Putra, G. (2017). Defining and sustaining the place-identity of a traditional yet rapidly developing city. Oxford Brookies University.

[22] Brennan-Horley, C., Connell, J., Gibson, C. (2007). The Parkes elvis revival festival: Economic development and contested place identities in rural Australia. Geographical Research, 45(1): 71-84. https://doi.org/10.1111/j.1745-5871.2007.00429.x

[23] Lee, C.K.C., Yap, C.S.F., Levy, D.S. (2016). Place identity and sustainable consumption: implications for social marketing. Journal of Strategic Marketing, 24(7): 578-593. https://doi.org/10.1080/0965254X.2016.1148758

[24] Manenti, C. (2011). Sustainability and place identity. Procedia Engineering, 21: 1104-1109. https://doi.org/10.1016/j.proeng.2011.11.2117

[25] de la Barre, S. (2013). Wilderness and cultural tour guides, place identity and sustainable tourism in remote areas. Journal of Sustainable Tourism, 21(6): 825-844. https://doi.org/10.1080/09669582.2012.737798

[26] Poespowardjo, S. (1986). Understanding local genius and its relevance in modernization. In Kepribadian Budaya Bangsa (Local Genius), Pustaka Jaya, pp. 28-38.

[27] Vecco, M., Montagner, E., Srakar, A. (2020). Genius loci: Between handcrafts, cultural heritage and local development. European Journal of Cultural Management \& Policy, 10(2): 64-75. https://www.encatc.org/media/5743-encatcjournal_issue2new.pdf\#page $=64$.

[28] Komariah, S. (2016). Local wisdom of ciptagelar community in managing environmental sustainability. 1st UPI International Conference on Sociology Education (UPI ICSE 2015) Local. https://doi.org/10.2991/icse-15.2016.39

[29] Ketut Rahyuda, I., Bagus Anom Purbawangsa, I., Bagus Ketut Surya, I. (2019). Relationship between competitive SMEs' orientation and "Catur Paramitha." International Journal of Social Economics, 46(7): 861-873. https://doi.org/10.1108/IJSE-01-2019-0004

[30] Syukur, M. (2015). Local wisdom in economic and social systems of bugis-wajo weaver community. Bandung Creative Movement (BCM) Journal, 2(1): 204-220.

[31] Lodra, I. (2016). Komodifikasi makna tenun gringsing sebagai "Soft Power" menghadapi budaya global. Jurnal Kajian Bali, 6(1): 211-222.

[32] UNCTAD. (2021). Creativity is the answer we've been looking for - now is the time to embrace and invest in it. https://Unctad.Org/News/Creativity-Answer-WeveBeen-Looking-Now-Time-Embrace-and-Invest-It.

[33] Cho, R.L.T., Liu, J.S., Ho, M.H.C. (2018). What are the concerns? Looking back on 15 years of research in cultural and creative industries. International Journal of Cultural Policy, 24(1): 25-44. https://doi.org/10.1080/10286632.2015.1128417

[34] Angelini, F., Castellani, M. (2019). Cultural and economic value: A critical review. Journal of Cultural Economics, 43(2):

173-188. https://doi.org/10.1007/s10824-018-9334-4

[35] Saskara, I.A.N., Marhaeni, A.A.I.N. (2017). The role of social capital and business strategies in developing the business of banten to increase balinese women's employment. Journal of Comparative Asian Development, $16(1)$ : 68-86. https://doi.org/10.1080/15339114.2017.1292930

[36] Pratt, A.C., Jeffcutt, P. (2009). Creativity, Innovation and the Cultural Economy. In Creativity, Innovation and the Cultural Economy. https://doi.org/10.4324/9780203880012

[37] Kerr, B. (2009). Creativity \& the economic system. Encyclopedia of Giftedness, Creativity, and Talent, 1-6.

[38] Fahmi, F.Z., Koster, S. (2017). Creative industries and regional productivity growth in the developing economy: Evidence from Indonesia. Growth and Change, 48(4): 805-830. https://doi.org/10.1111/grow.12212

[39] UNESCO. (2015). Re | Shaping Cultural Policies. In the United Nations Educational, Scientific and Cultural Organization (UNESCO).

[40] Papazoglou, G. (Emmy). (2019). Society and culture: Cultural policies driven by local authorities as a factor in local development - the example of the municipality of Xanthi-Greece. Heritage, 2(3): 2625-2639. https://doi.org/10.3390/heritage2030161

[41] Petrova, L. (2011). David Throsby: The economics of cultural policy. Journal of Cultural Economics, 35(3): 237-240. https://doi.org/10.1007/s10824-011-9138-2

[42] Fahmi, F.Z. (2016). Creative industries and regional economic development in Indonesia: Meanings, patterns and impacts. [Groningen]: University of Groningen.

[43] Hair, J.F., Risher, J.J., Sarstedt, M., Ringle, C.M. (2019). When to use and how to report the results of PLS-SEM. European Business Review, 31(1): 2-24. https://doi.org/10.1108/EBR-11-2018-0203

[44] Lee, A., Wall, G. (2012). Food Clusters: Towards a Creative Rural Economy. May, 13.

[45] Nakatani, A. (1999). Chapter 7. "Eating Threads": Brocades as cash crop for weaving mothers and daughters in Bali. Staying Local in the Global Village, University of Hawaii Press. https://doi.org/doi:10.1515/9780824864460-011

[46] Vitasurya, V.R. (2016). Local wisdom for sustainable development of rural tourism, case on Kalibiru and Lopati village, province of Daerah Istimewa Yogyakarta. Procedia - Social and Behavioral Sciences, 216: 97-108. https://doi.org/10.1016/j.sbspro.2015.12.014

[47] Gunaisah, E., Saleh, Y., Nayan, N., Caropeboka, R.M. (2016). Socio-economic and cultural sustainability in local wisdom management at local marine conservation area (KKLD) of Mayalibit Bay, Raja Ampat Regency, West Papua Province. AACL Bioflux, 9(4): 901-909.

[48] Mahyarni, Meflinda, A., Bustam, N., Tanjung, H. (2015). Mapping dan strategi pengembangan potensi ekonomi berbasis budaya lokal di Provinsi Riau. Jurnal Aplikasi Manajemen, 13(4): 620-633.

[49] Throsby, D. (2010). The Economics of Cultural Policy. Cambridge University Press. https://doi.org/10.1017/CBO9780511845253

[50] Antari, N.P.B.W., Jannah, L.M. (2016). The role of denpasar government in supporting the resources of endek fabric creative industry. Bisnis \& Birokrasi Journal, $22(1)$ : 16-35. https://doi.org/10.20476/jbb.v22i1.5426 